\title{
Phloretin Promotes Adipogenesis via Mitogen-Activated Protein Kinase Pathways in Mouse Marrow Stromal ST2 Cells
}

\author{
Ayumu Takeno ${ }^{(\mathbb{D})}$, Ippei Kanazawa * ${ }^{\mathbb{D}}$, Masakazu Notsu, Ken-ichiro Tanaka and \\ Toshitsugu Sugimoto
}

Internal Medicine 1, Shimane University Faculty of Medicine, 89-1, Enya-cho, Izumo, Shimane 693-8501, Japan; atakeno@med.shimane-u.ac.jp (A.T.); mnotsu25@med.shimane-u.ac.jp (M.N.);

ken1nai@med.shimane-u.ac.jp (K.T.); sugimoto@med.shimane-u.ac.jp (T.S.)

* Correspondence: ippei.k@med.shimane-u.ac.jp; Tel.: +81-853-20-2183; Fax: +81-853-23-8650

Received: 11 June 2018; Accepted: 13 June 2018; Published: 14 June 2018

\begin{abstract}
Phloretin, a glucose transporter (GLUT) inhibitor, has pleiotropic effects. The present study examined the effects of phloretin on the commitment of marrow stromal cells to adipocytes, using the mouse marrow stromal cell line ST2. Oil red O staining showed that treatment with phloretin 10-100 $\mu \mathrm{M}$ promoted lipid accumulation. Real-time PCR showed that phloretin significantly increased the expression of adipogenic markers, including $\operatorname{PPAR} \gamma, \mathrm{C} / \mathrm{EBP} \alpha$, fatty acid synthase, fatty acid-binding protein 4 , and adiponectin. Western blotting showed that phloretin inhibited ERK1/2 and JNK but activated p38 MAPK. Treatment with a MAPK/ERK kinase inhibitor and a JNK inhibitor enhanced adipogenesis, similar to phloretin. In contrast, a p38 MAPK inhibitor suppressed phloretin-induced adipogenesis. Although phloretin phosphorylated AMP-activated protein kinase (AMPK), co-incubation with an AMPK inhibitor did not block phloretin-induced adipogenesis. The 2-deoxyglucose colorimetric assay showed that phloretin and siRNA silencing of GLUT1 decreased glucose uptake. However, unlike phloretin treatment, GLUT1 silencing inhibited adipogenesis. In addition, phloretin enhanced adipogenesis in GLUT1 knocked-down cells. Taken together, phloretin induced adipogenesis of marrow stromal cells by inhibiting ERK1/2 and JNK and by activating p38 MAPK. The adipogenic effects of phloretin were independent of glucose uptake inhibition. Phloretin may affect energy metabolism by influencing adipogenesis and adiponectin expression.
\end{abstract}

Keywords: phloretin; adipogenesis; glucose uptake; marrow stromal ST2 cells; mitogen-activated protein kinase; adenosine monophosphate-activated protein kinase

\section{Introduction}

Adipose tissue is a crucial organ that regulates energy homeostasis. In addition to energy storage, adipose tissue functions as an endocrine organ. Adipocytes secrete adipokines, such as adiponectin (APN), leptin, and resistin, thereby regulating whole body metabolism [1]. Accumulation of visceral fat causes the dysregulation of adipokine secretions, leading to metabolic abnormalities including insulin resistance [1]. The adipocyte differentiation process is orchestrated by a network of transcriptional cascades, involving molecules such as the CCAAT/enhancer-binding protein (C/EBP) family members and peroxisome proliferator-activated receptor $\gamma$ (PPAR $\gamma)$, which play central roles in adipocyte differentiation by regulating the expression of adipocyte-specific genes [2-4].

Phloretin (2', 4',6'-trihydroxy-3-(4-hydroxyphenyl)-propiophenone) is a natural phenolic compound present in fruits, such as apples [5] and strawberries [6]. It has been reported that 
phloretin has pleiotropic effects, including anti-oxidative [7-9] and anti-inflammatory activities [10,11]. In addition, phloretin is a known inhibitor of glucose transporter (GLUT) [12] and is reported to suppress cancer growth by inhibiting glucose uptake through GLUT2 [13-16]. The effect of phloretin on adipogenesis has also been reported. In vitro studies have shown that treatment with phloretin increases the expression of PPAR $\gamma$ and C/EBP $\alpha$ and promotes adipocyte differentiation in mouse 3T3-L1 preadipocytes and porcine primary adipocytes, respectively $[17,18]$. On the other hand, Huang et al. reported that phloretin promoted lipolysis in fully differentiated mature 3T3-L1 cells [19]. These results indicate that phloretin may facilitate adipogenesis in preadipocytes and promote lipolysis in mature adipocytes. Several in vivo studies have shown that the administration of phloretin improves hyperglycemia, insulin resistance [20,21], and obesity [20] in diabetic rodent models. However, no studies have investigated the effects of phloretin on the commitment of multipotent marrow stromal cells (MSCs) to the adipocytes and its underlying mechanisms, including the contribution of glucose uptake inhibition.

Adenosine monophosphate-activated protein kinase (AMPK) is known as an intracellular energy sensor and plays crucial roles in the regulation of whole body energy metabolism [22]. AMPK senses energy shortage and suppresses energy consumption, i.e., lipogenesis, protein synthesis, and gluconeogenesis, while enhancing energy production, i.e., glucose uptake and fatty acid oxidation [22,23]. It has been reported that AMPK is a negative regulator of adipogenesis [24-27]. However, its precise mechanism remains to be elucidated. Furthermore, previous studies have shown that mitogen-activated protein kinase (MAPK) family, including extracellular signal-regulated kinase (ERK) 1/2, c-Jun N-terminal kinase (JNK) and p38 MAPK are associated with adipocyte differentiation $[2,28]$. We and other researchers have previously reported that phloretin promotes the phosphorylation of AMPK $[19,29]$ and alters the phosphorylation status of MAPKs $[11,18,29-31]$ in various cell types. However, it is unclear whether the effects of phloretin on adipogenesis are mediated by AMPK or MAPKs.

In this study, we examined the effects of phloretin on adipocyte differentiation using the mouse MSC line ST2, and the involvement of the downstream signalling pathways linked to AMPK and MAPK. We also investigated whether the effects of phloretin were mediated by glucose uptake inhibition through GLUT.

\section{Results}

\subsection{Effects of Phloretin on Adipocyte Differentiation in ST2 Cells}

We examined the effects of phloretin on adipogenesis in ST2 cells. Oil Red O staining and its quantification showed that treatment with phloretin $(50$ and $100 \mu \mathrm{M})$ significantly increased lipid deposition (Figure 1A), and the maximum effect was observed at $50 \mu \mathrm{M}$ phloretin (Figure 1B). We also examined the mRNA expression of important adipogenic transcription factors (Ppar $\gamma$ and $C / e b p \alpha$ ) and adipocyte differentiation markers, fatty acid synthase (Fas), fatty acid-binding protein 4 (Fabp4) and adiponectin (Apn). Treatment with phloretin increased the mRNA expression of all the above-mentioned factors (Figure $1 C-G$ ). The maximum effects were observed at $50 \mu \mathrm{M}$ phloretin (Figure 1C-G). the adipogenic markers Pparr, C/ebp . 
A

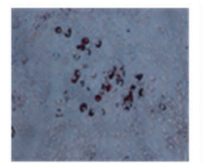

$\mathbf{0}$

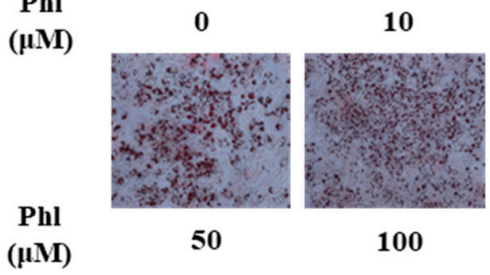

B

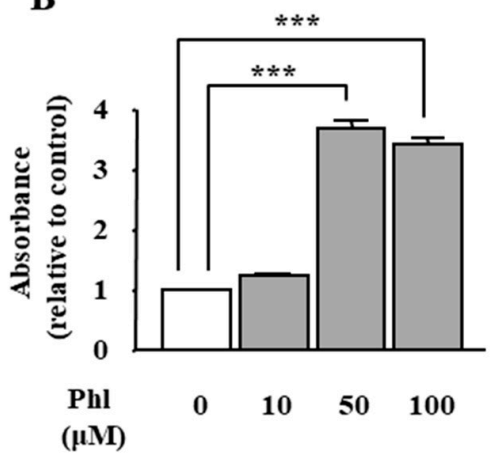

C

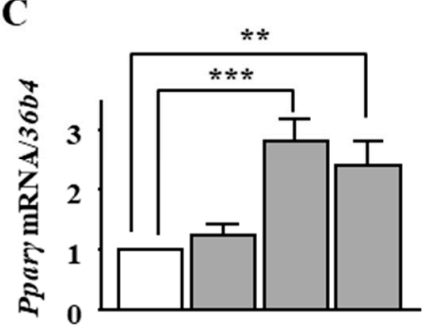

$\begin{array}{lllll}\text { Phl } & 0 & 10 & 50 & 100\end{array}$

$(\mu \mathrm{M})$

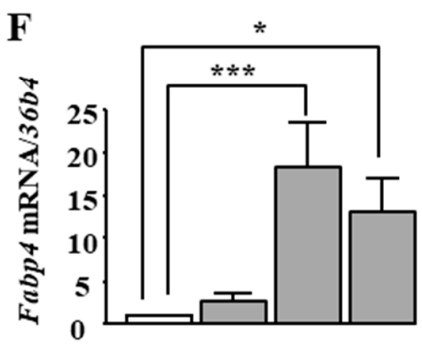

$\begin{array}{lllll}\text { Phl } & 0 & 10 & 50 & 100\end{array}$
D

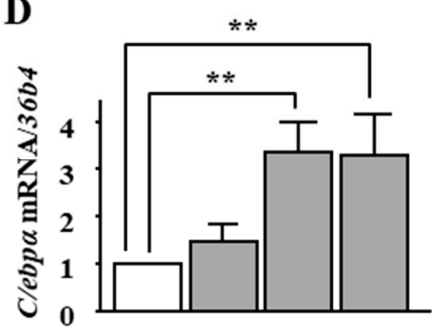

$\begin{array}{lllll}\text { Phl } & 0 & 10 & 50 & 100\end{array}$ $(\mu \mathrm{M})$
$\mathbf{E}$

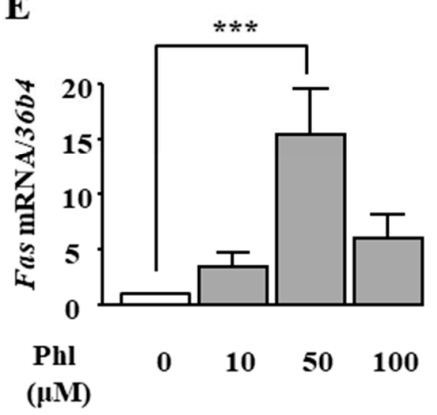

G

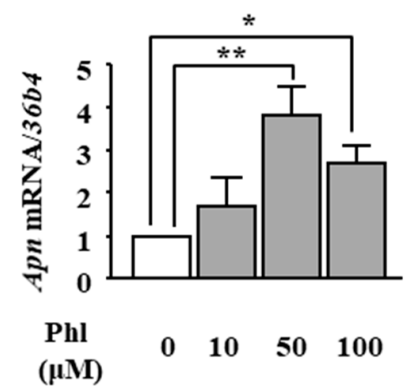

Figure 1. The effects of phloretin on adipocyte differentiation in ST2 cells. (A,B) After reaching confluency, ST2 cells were incubated in adipogenic medium with phloretin $(0,10,50$, and $100 \mu \mathrm{M})$, and oil red $\mathrm{O}$ staining was performed at day 8 . The results are representative of at least seven different experiments. The quantification results are expressed as mean $\pm \mathrm{SE}(n=6)$; ${ }^{* * *} p<0.001$. (C-G) After reaching confluency, the cells were incubated in adipogenic medium. The mRNA expression of adipogenic differentiation markers (Ppar, C/ebp $\alpha, F a s, F a b p 4$, and Apn) was examined by real-time PCR at day 4. The results are expressed as mean \pm SE $(n \geq 5) ;{ }^{*} p<0.05,{ }^{* *} p<0.01,{ }^{* * *} p<0.001$. Phl: phloretin.

\subsection{Role of AMPK in the Phloretin-Induced Upregulation of Adipocyte Differentiation Markers}

Next, we examined whether AMPK is involved in phloretin-induced adipocyte differentiation in ST2 cells. After ST2 cells were incubated in adipogenic differentiation medium for two days, the effect of phloretin on the phosphorylation of AMPK was examined by western blotting. Treatment with phloretin $(100 \mu \mathrm{M})$ enhanced the phosphorylation of AMPK (Figure 2A). Moreover, treatment with phloretin $(10-100 \mu \mathrm{M})$ for 1 and $12 \mathrm{~h}$ dose-dependently enhanced the phosphorylation of AMPK (Figure 2B). The quantification of the bands showed that the increase in the ratio of phosphorylated AMPK to total AMPK was significant (Figure 2C,D). The treatment with the AMPK inhibitor ara-A $(0.1 \mathrm{mM})$ alone did not alter the expression of the adipocyte differentiation markers (Figure 2F-I), 
although it slightly increased Ppary expression (Figure 2E). Co-incubation with ara-A slightly but significantly suppressed phloretin-induced upregulation of Fabp4 (Figure $2 \mathrm{H}$ ), whereas the expression of other adipocyte differentiation markers was not affected (Figure 2E-G,I). These findings indicate that the phosphorylation of AMPK may not be associated with phloretin-induced upregulation of adipocyte differentiation markers in ST2 cells.

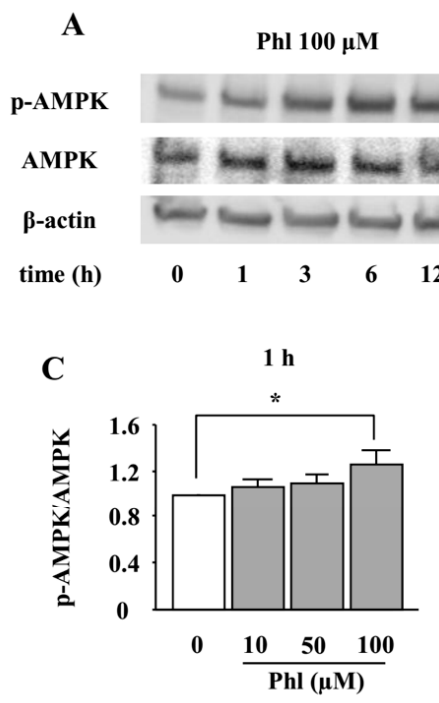

B

\section{p-AMPK \\ AMPK \\ $\beta$-actin}

Phl ( $\mu M)$
$1 \mathrm{~h}$

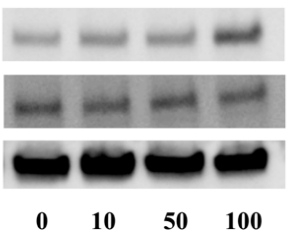

$12 \mathrm{~h}$

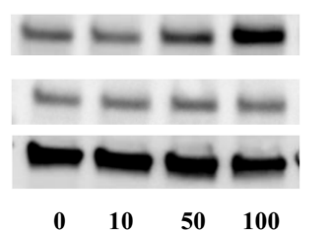

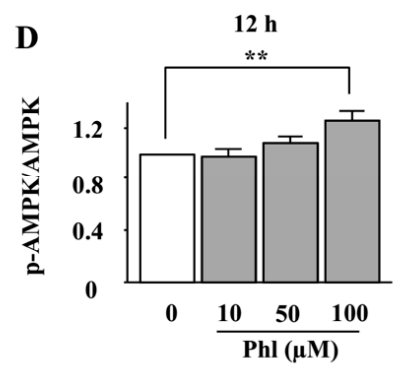

$\mathbf{E}$

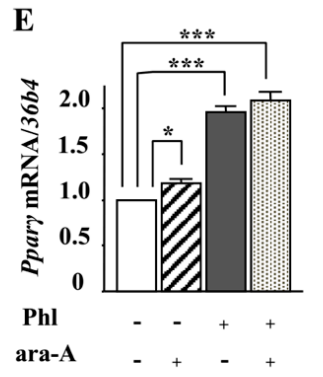

$\mathbf{F}$

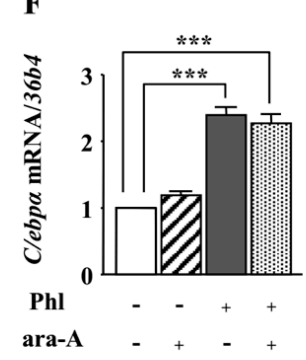

G

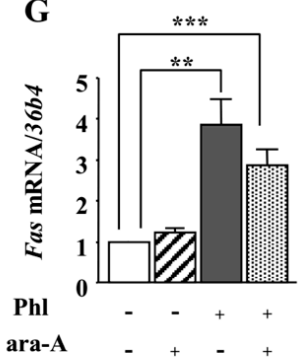

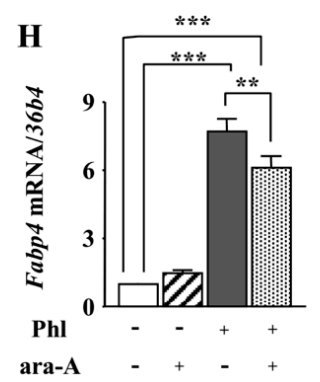

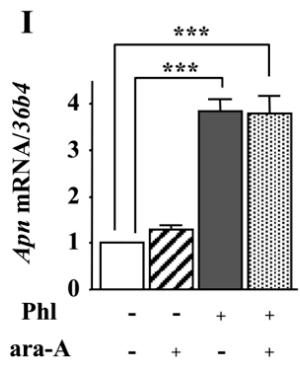

Figure 2. The effects of the AMPK inhibitor ara-A on phloretin-induced upregulation of adipocyte differentiation markers. (A-D) After reaching confluency, ST2 cells were incubated in adipogenic medium for $48 \mathrm{~h}$. Thereafter, the cells were treated with $100 \mu \mathrm{M}$ phloretin for up to $12 \mathrm{~h}$, and western blot analysis was performed to examine the time-dependent effects of phloretin on AMPK (A). To test dose dependency, the cells were treated with phloretin $(0$ to $100 \mu \mathrm{M})$ for 1 and $12 \mathrm{~h}(\mathbf{B})$. Quantification of the bands was performed $(\mathbf{C}, \mathbf{D})$. The results are representative of at least four experiments. The quantification results are expressed as mean $\pm \mathrm{SE}(n \geq 4) ;{ }^{*} p<0.05,{ }^{* *} p<0.01$. (E-I) After reaching confluency, the cells were incubated in adipogenic medium with $100 \mu \mathrm{M}$ phloretin and/or $0.1 \mathrm{mM}$ ara-A for 4 days. The mRNA expression of adipogenic differentiation markers (Ppary, C/ebpa, Fas, Fabp4, and Apn) was examined by real-time PCR. The results are expressed as mean $\pm \mathrm{SE}$ $(n \geq 7) ;{ }^{*} p<0.05,{ }^{* *} p<0.01,{ }^{* * *} p<0.001$. Phl: phloretin. 


\subsection{The Effects of Phloretin on the Phosphorylation of MAPKs in ST2 Cells}

We examined the effects of phloretin on the phosphorylation of MAPKs, i.e., ERK1/2, JNK, and p38 MAPK. ST2 cells were incubated in adipogenic differentiation medium for two days, and then the effect of phloretin on the phosphorylation of MAPKs was examined by western blotting. The treatment with phloretin $(100 \mu \mathrm{M})$ suppressed the phosphorylation of ERK1/2 and JNK up to $12 \mathrm{~h}$ (Figure $3 \mathrm{~A}$ ). Moreover, phloretin dose-dependently decreased the phosphorylation of ERK1/2 and JNK (Figure 3B). The densitometric analysis of the bands showed a significant decrease in the level of phosphorylated ERK1/2 at both 1 and $12 \mathrm{~h}$, and of phosphorylated JNK at $12 \mathrm{~h}$ (Figure 3C,D,F,G). On the other hand, the treatment with phloretin $(100 \mu \mathrm{M})$ transiently phosphorylated p38 MAPK, and, then, suppressed p38 MAPK expression (Figure 3A). Phloretin (10-100 $\mu \mathrm{M})$ dose-dependently increased the phosphorylation of p38 MAPK at $1 \mathrm{~h}$ and decreased it at $12 \mathrm{~h}$ (Figure 3B). The densitometric analysis showed that the effects of phloretin on the phosphorylation of p38 MAPK were significant at both 1 and $12 \mathrm{~h}$ (Figure 3E,H).
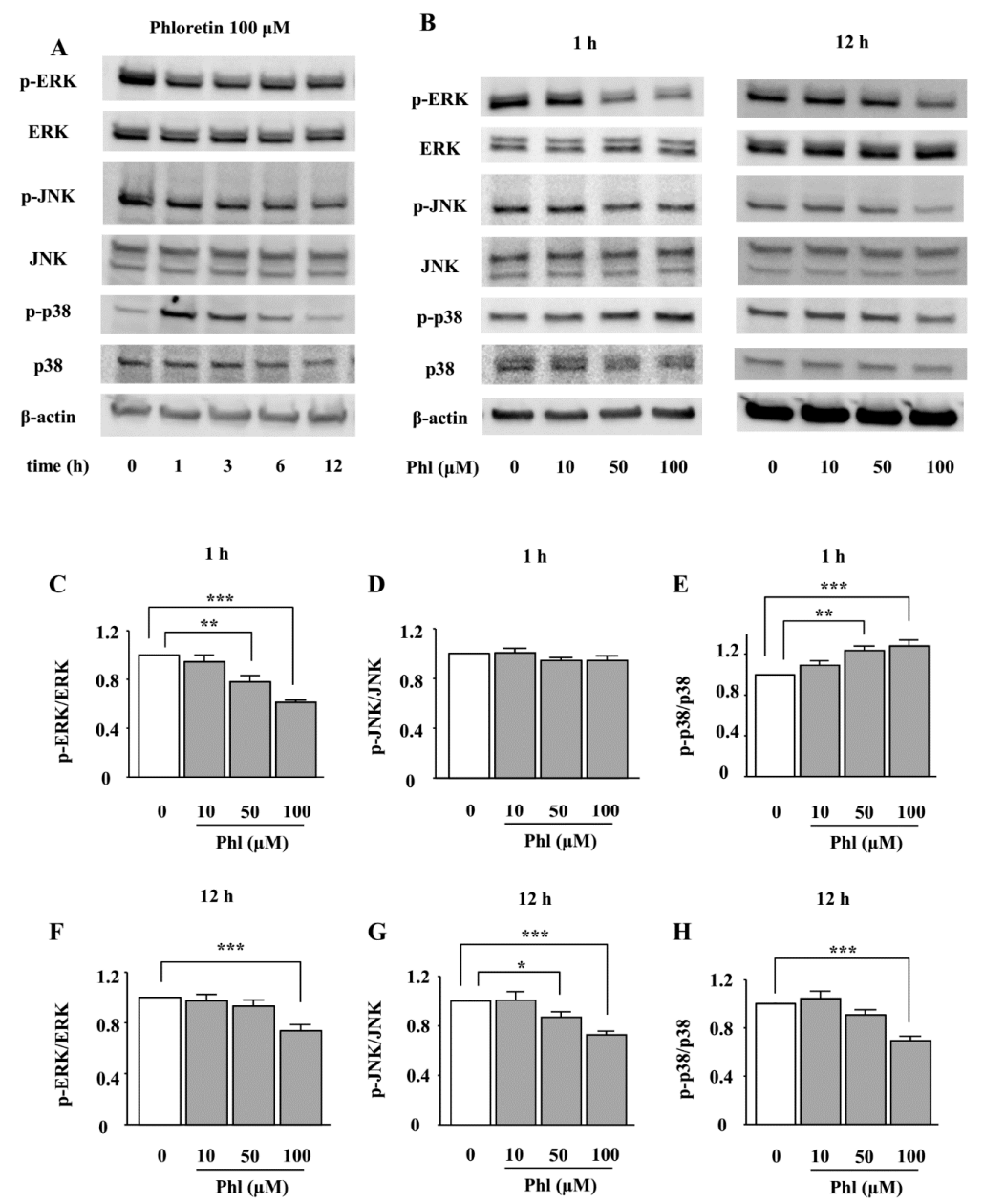

Figure 3. The effects of phloretin on the phosphorylation of MAPKs in ST2 cells. (A-H) After reaching confluency, ST2 cells were incubated in adipogenic medium for $48 \mathrm{~h}$. Thereafter, the cells were treated with $100 \mu \mathrm{M}$ phloretin for up to $12 \mathrm{~h}$, and western blot analysis was performed to examine the time-dependent effects of phloretin on the phosphorylation of ERK1/2, JNK, and p38 MAPK (A). To test dose dependency, the cells were treated with phloretin $(0$ to $100 \mu \mathrm{M})$ for 1 and $12 \mathrm{~h}(\mathbf{B})$. The results are representative of at least five experiments. (C-H) The quantification results are expressed as mean $\pm \mathrm{SE}$ $(n \geq 5) ; * p<0.05,{ }^{* *} p<0.01,{ }^{* * *} p<0.001$. Phl: phloretin. 


\subsection{The Effects of ERK1/2 Inhibition on Adipocyte Differentiation in ST2 Cells}

To examine whether ERK1/2 inhibition is involved in phloretin-induced adipocyte differentiation in ST2 cells, we used the MAPK/ERK kinase (MEK) inhibitor PD98059. Treatment with PD98059 $(10$ and $20 \mu \mathrm{M})$ dose-dependently promoted lipid accumulation, as confirmed by oil red $\mathrm{O}$ staining (Figure 4A). The quantification of oil red O staining showed that the PD98059-induced increase in lipid deposition was significant (Figure 4B). In addition, the mRNA expression of Ppar, , Clebp $\alpha$, Fas, Fabp4, and Apn was significantly increased by PD98059 treatment $(20 \mu \mathrm{M})$ (Figure 4C-G).

A

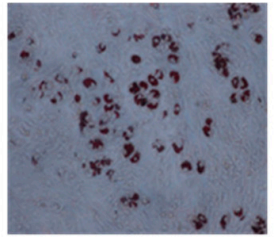

PD98059

$(\mu \mathrm{M})$ $(\times 100)$

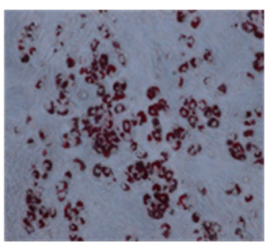

10

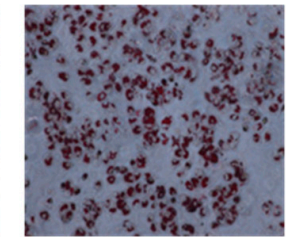

20
$\mathbf{B}$

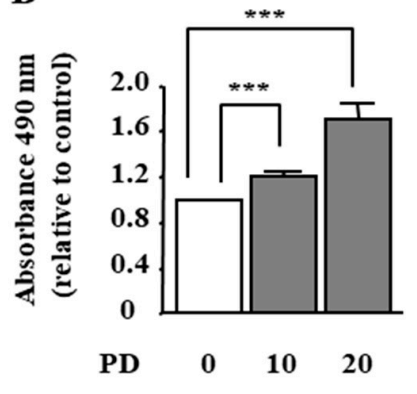

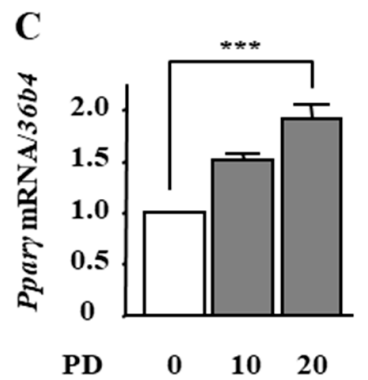
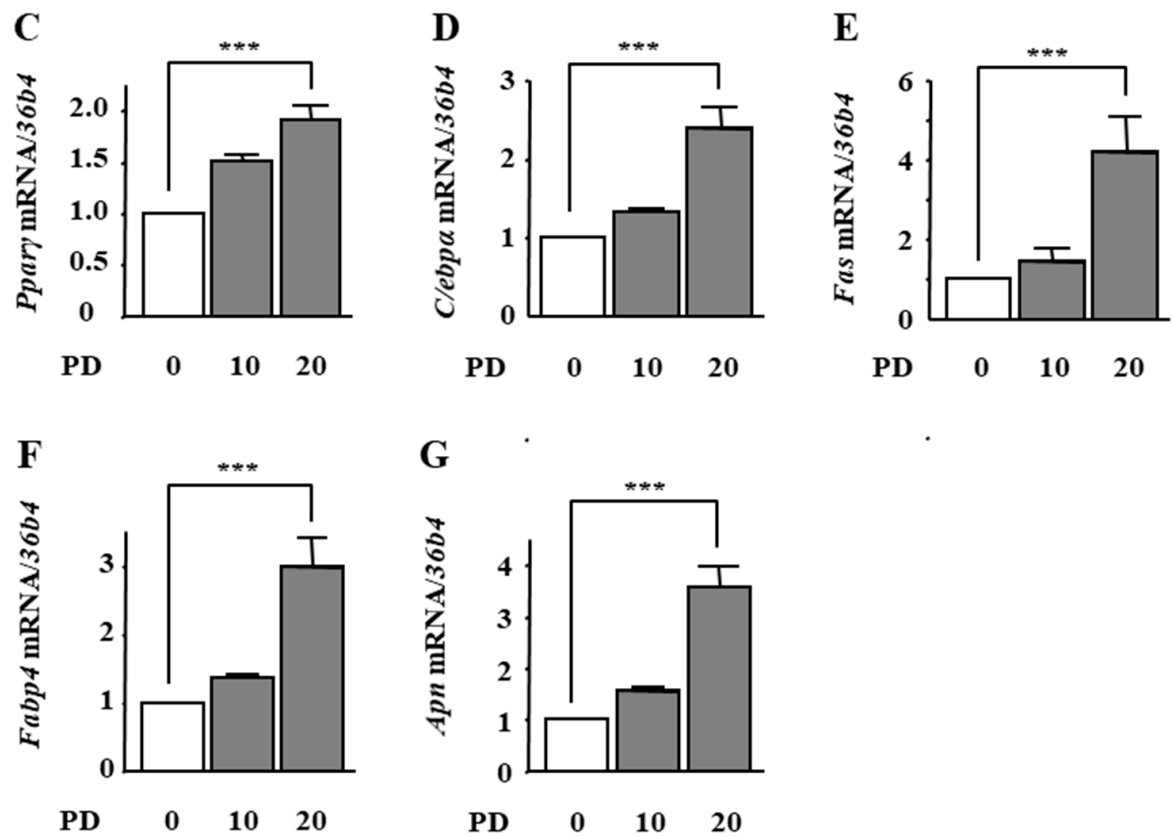

Figure 4. The effects of the MEK inhibitor PD98059 on adipocyte differentiation in ST2 cells. (A,B) After reaching confluency, ST2 cells were incubated in adipogenic medium with the MEK inhibitor PD98059 $(0,10$, and $20 \mu \mathrm{M})$ for 8 days. Thereafter, oil red $\mathrm{O}$ staining and its quantification were performed. The results are representative of at least seven different experiments. The quantification results are expressed as mean $\pm \mathrm{SE}(n=8) ;{ }^{* * *} p<0.001$. (C-G) After reaching confluency, the cells were incubated in adipogenic medium with $\operatorname{PD} 98059(0,10$, and $20 \mu \mathrm{M})$ for 4 days. The mRNA expression of adipogenic differentiation markers (Ppar, , C/ebp $\alpha$, Fas, Fabp4, and Apn) was examined by real-time PCR. The results are expressed as mean $\pm \operatorname{SE}(n=7) ;{ }^{* * *} p<0.001$. PD: PD98059.

\subsection{The Effects of JNK Inhibition on Adipocyte Differentiation in ST2 Cells}

To examine the effect of phloretin-induced JNK inhibition on adipocyte differentiation in ST2 cells, we used the JNK inhibitor SP600125. Oil Red O staining and its quantification showed that the treatment with SP600125 (5 and $10 \mu \mathrm{M}$ ) significantly increased lipid deposition (Figure 5A,B). 
Moreover, the mRNA expression of Ppar, , Clebp $\alpha$, Fas, Fabp4, and Apn was significantly increased by $10 \mu \mathrm{M}$ SP600125 (Figure 5C-G).

A

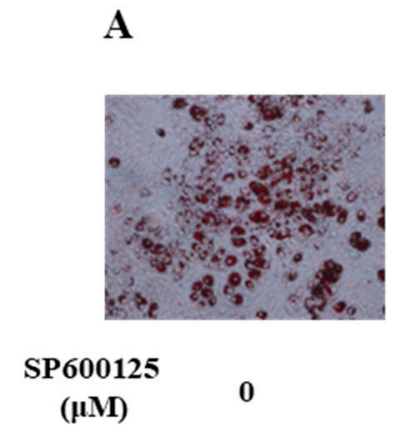

C

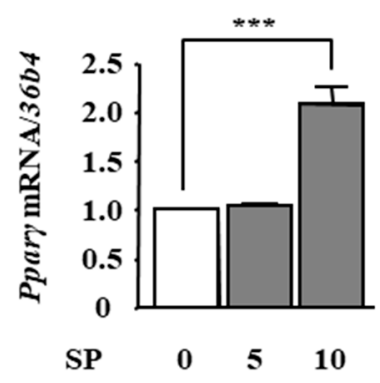

$\mathbf{F}$

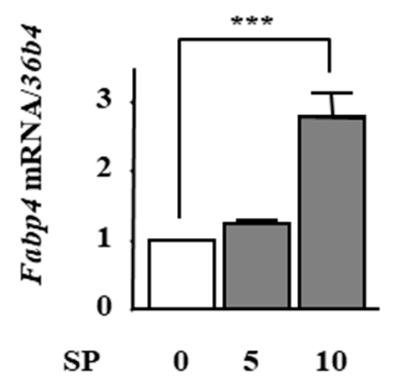

$(\times 100)$

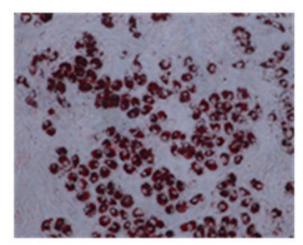

5
B

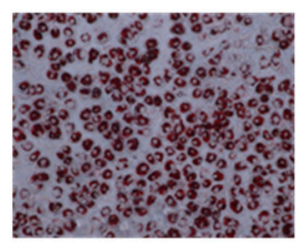

10

D

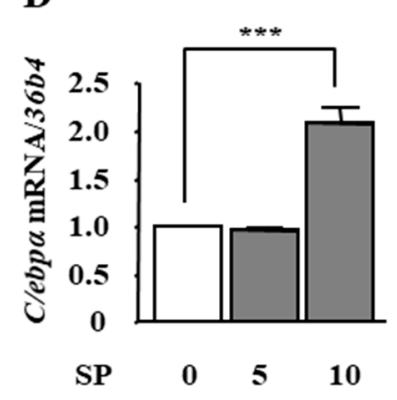

G

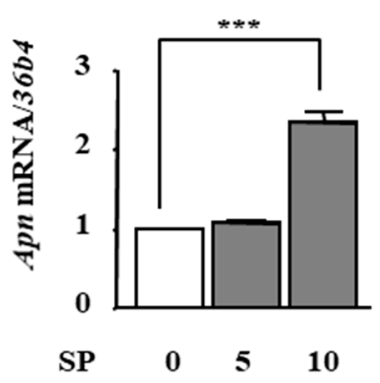

$\mathbf{E}$

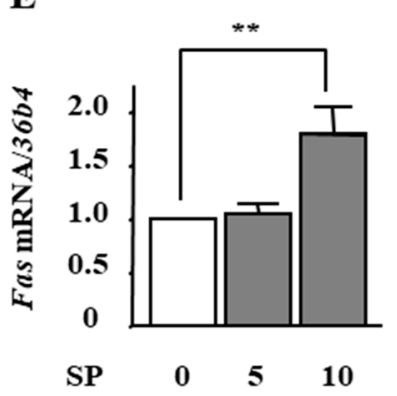

Figure 5. The effects of the JNK inhibitor SP600125 on adipocyte differentiation in ST2 cells. (A,B) After reaching confluency, ST2 cells were incubated in adipogenic medium with the JNK inhibitor SP6001215 $(0,5$, and $10 \mu \mathrm{M})$ for 8 days. Thereafter, oil red $\mathrm{O}$ staining and its quantification were performed. The results are representative of at least seven different experiments. The quantification results are expressed as mean $\pm \mathrm{SE}(n=8) ;{ }^{* * *} p<0.001$. (C-G) After reaching confluency, the cells were incubated in adipogenic medium with $\operatorname{PD} 98059(0,10$, and $20 \mu \mathrm{M})$ for 4 days. The mRNA expression of adipogenic differentiation markers (Ppar, Clebp $\alpha$, Fas, Fabp4, and Apn) was examined by real-time PCR. The results are expressed as mean \pm SE $(n=7) ;{ }^{* *} p<0.01,{ }^{* * *} p<0.001$. SP: SP600125.

\subsection{The Effects of p38 MAPK Inhibition on Phloretin-Induced Adipogenesis in ST2 Cells}

We investigated whether phloretin-induced activation of p38 MAPK is involved in adipogenesis in ST2 cells. Oil red O staining and its quantification showed that $50 \mu \mathrm{M}$ phloretin significantly increased lipid deposition, which was significantly inhibited by co-incubation with the p38 MAPK inhibitor SB203580 $(1 \mu \mathrm{M})$. In addition, treatment with $50 \mu \mathrm{M}$ phloretin significantly increased the expression of the adipocyte differentiation markers, Ppary, Clebpa, Fas, Fabp4, and Apn, and co-incubation with $1 \mu \mathrm{M}$ SB203580 partially but significantly suppressed phloretin-induced upregulation of the 
adipogenic markers (Figure 6C-G). The treatment with SB203580 alone had no effects on lipid deposition (Figure 6A,B) and adipogenic marker expression (Figure 6C-G).
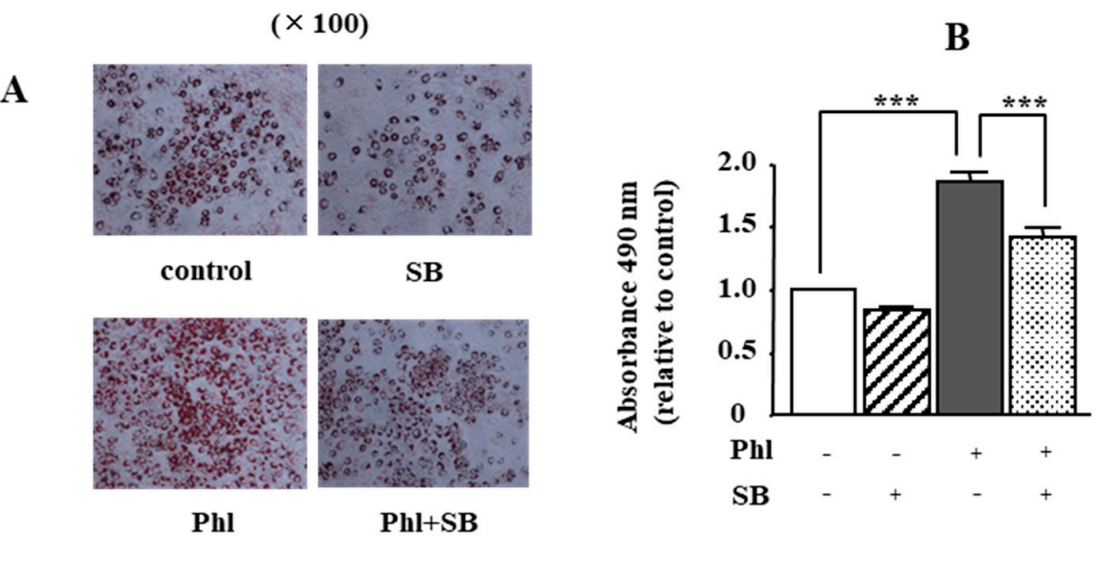

D

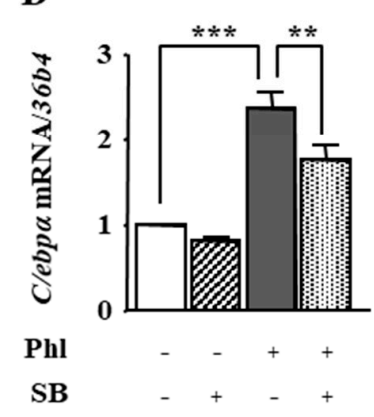

G

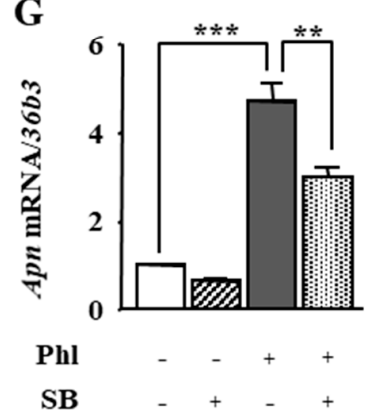

SB
$\mathbf{E}$

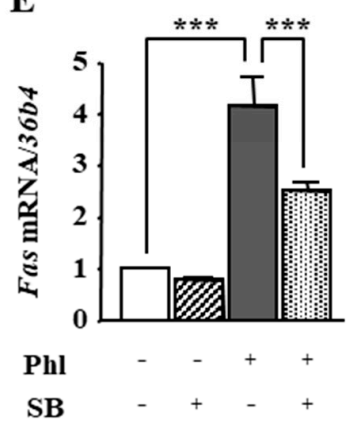

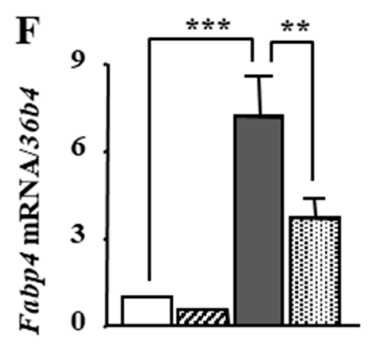

Phl

SB

$-++$
C

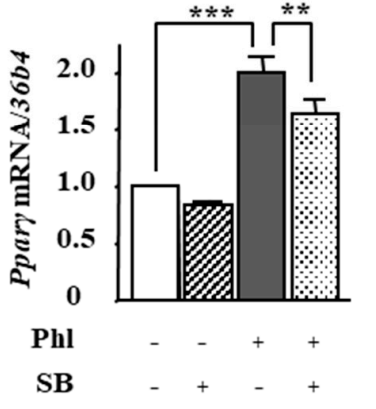

Figure 6. The effects of the p38 MAPK inhibitor SB203580 on phloretin-induced adipogenesis in ST2 cells. (A,B) After reaching confluency, ST2 cells were incubated in adipogenic medium with phloretin $(50 \mu \mathrm{M})$ and/or SB203580, a p38 MAPK inhibitor $(0,5$, and $10 \mu \mathrm{M})$ for 5 days. Thereafter, oil red O staining and its quantification were performed. The results are representative of at least seven different experiments. The quantification results are expressed as mean $\pm \mathrm{SE}(n=6) ;{ }^{* * *} p<0.001$. (C-G) After reaching confluency, the cells were incubated in adipogenic medium with $\operatorname{SB} 203580(0,5$, and $10 \mu \mathrm{M})$ for 4 days. The mRNA expression of adipogenic differentiation markers (Ppary, Clebp $\alpha$, Fas, Fabp4, and Apn) was examined by real-time PCR. The results are expressed as mean $\pm \operatorname{SE}(n=5) ; * * p<0.01$, *** $p<0.0011$. Phl: phloretin, SB: SB203580.

\subsection{The Involvement of Glucose Uptake Inhibition on Adipocyte Differentiation in ST2 Cells}

The effect of phloretin on glucose uptake in ST2 cells was measured by using the 2-deoxyglucose (2-DG) colorimetric assay. Treatment with phloretin (10-100 $\mu \mathrm{M})$ significantly inhibited 2-DG uptake 
in the cells (Figure 7A). We have previously shown that ST2 cells express only GLUT1, among all the members of the GLUT subfamily [29]. We investigated whether the adipogenic effects of phloretin are mediated by glucose uptake inhibition induced by Glut1 silencing. RT-PCR and real-time PCR showed that Glut1 small interfering RNA (siRNA) significantly suppressed the expression of Glut1 mRNA, compared with the negative control siRNA (Figure 7B,C), and decreased glucose uptake (Figure 7D). In contrast to the effects of phloretin, oil red O staining showed that the knockdown of Glut1 markedly suppressed lipid accumulation (Figure 7E). Furthermore, the knockdown of Glut1 significantly decreased the expression of the adipogenic markers Ppar , Clebp $\alpha$, Fas, Fabp4, and Apn (Figure 7F-J).
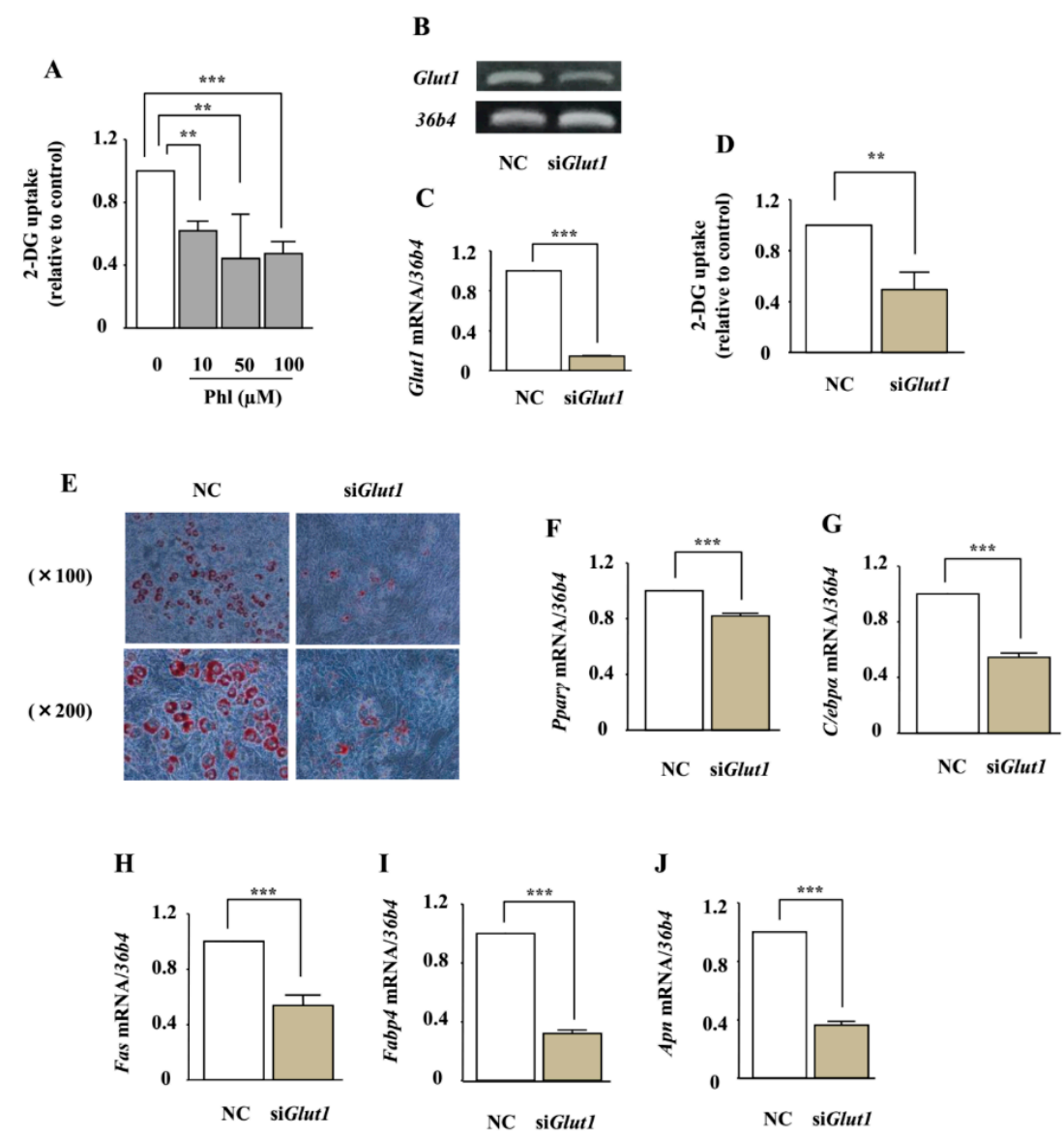

Figure 7. The role of glucose uptake inhibition in adipocyte differentiation in ST2 cells. (A) After pre-incubation in Krebs-Ringer Phosphate-Hepes (KRPH) buffer containing 0-100 $\mu \mathrm{M}$ phloretin, the cells were treated with 2-DG containing phloretin 0-100 $\mu \mathrm{M}$, and then the colorimetric uptake assay was performed. The results are expressed as mean $\pm \mathrm{SE}(n \geq 3) ;{ }^{* *} p<0.01,{ }^{* * *} p<0.001$. (B,C) After transfection with Glut1 and non-specific control siRNA, the mRNA expression of Glut1 was examined by RT-PCR (B) and real-time PCR (C). The housekeeping gene $36 b 4$ was used to normalize the differences in the efficiencies of reverse transcription. The results are expressed as mean $\pm \mathrm{SE}$ $(n=6) ;{ }^{* * *} p<0.001$. NC: negative control. (D) After transfection with Glut1 or scramble control siRNA, the cells were incubated in KRPH buffer for $20 \mathrm{~min}$, treated with 2-DG containing 0-100 $\mu \mathrm{M}$ phloretin, and then the colorimetric assay was performed. The results are expressed as mean $\pm \operatorname{SE}(n=6)$; ** $p<0.01$. (E) After transfection with Glut1 and non-specific control siRNA, the cells were incubated in adipogenic medium for 8 days, and oil red $\mathrm{O}$ staining was performed. (F-J) After transfection with Glut1 and non-specific control siRNA, the cells were incubated in adipogenic differentiation medium for 4 days. The mRNA expression of adipogenic differentiation markers (Ppar, C/ebp $\alpha$, Fas, Fabp4, and Apn) was examined by real-time PCR. The results are expressed as mean $\pm \operatorname{SE}(n \geq 4) ;{ }^{* * *} p<0.001$. 


\subsection{The Effect of Phloretin on Adipocyte Differentiation in Glut1 Knocked-Down ST2 Cells}

To further investigate the involvement of glucose uptake inhibition in phloretin-induced adipogenesis, we examined the effects of phloretin on lipid deposition and expression of adipocyte differentiation markers in Glut1 knocked-down ST2 cells. After transfection with control or Glut1 siRNA, the cells were incubated in adipogenic medium containing phloretin at a concentration of 0 to $100 \mu \mathrm{M}$. Oil red O staining showed that the silencing of Glut1 decreased lipid deposition; on the other hand, treatment with phloretin 10-100 $\mu \mathrm{M}$ increased lipid deposition even in the Glut1 knocked-down cells (Figure 8A). In addition, real-time PCR showed that the silencing of Glut1 significantly decreased the expression of Clebpa, Fas, Fabp4, and Apn and slightly but not significantly decreased the expression of Ppary, that treatment with phloretin $50 \mu \mathrm{M}$ facilitated the expression of Ppary and Apn, and that phloretin 50 and $100 \mu \mathrm{M}$ enhanced the expression of C/ebpa, Fas, and Fabp4 in Glut1 knocked-down ST2 cells (Figure 8B-F). These findings demonstrated that phloretin promoted adipogenesis in ST2 cells independent of glucose uptake inhibition.

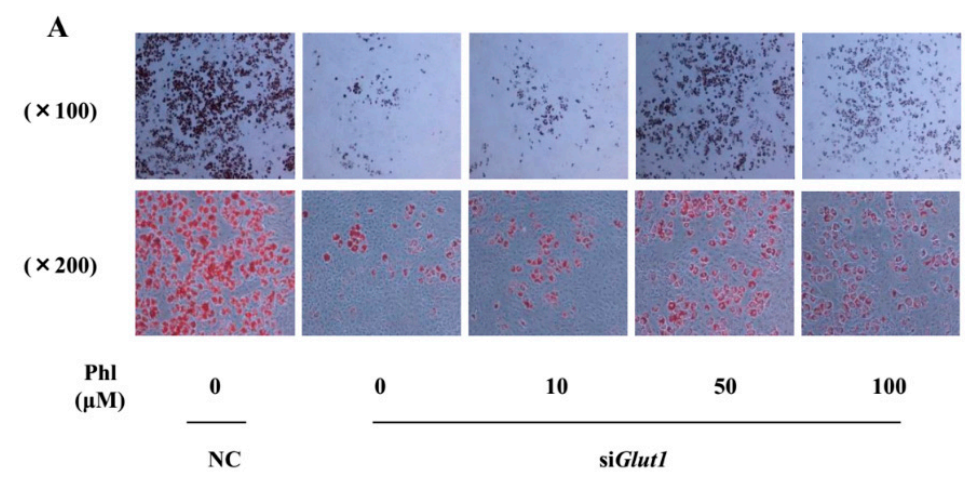

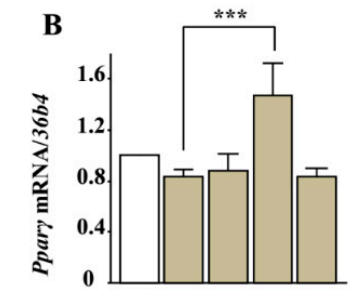
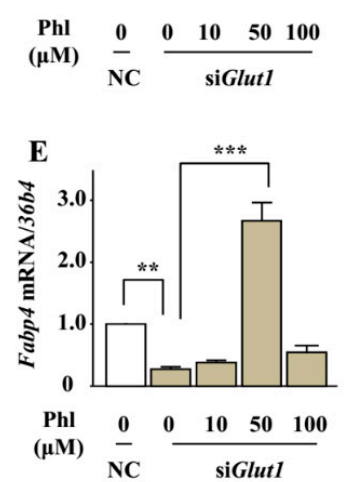
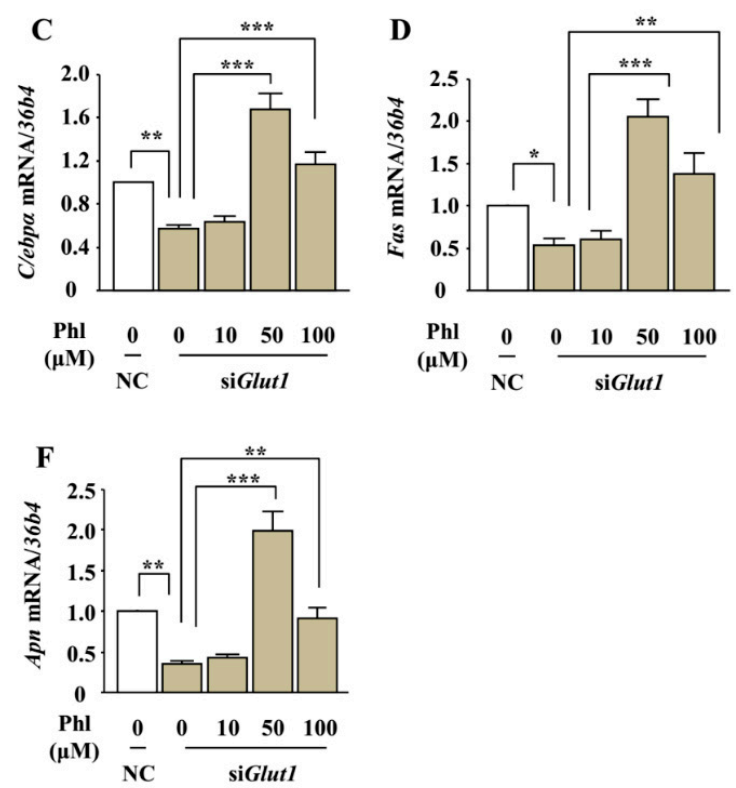

Figure 8. The effect of phloretin on adipocyte differentiation in Glut1 knocked-down ST2 cells. (A) After transfection with control or Glut1 siRNA, the cells were incubated in adipogenic medium containing phloretin 0-100 $\mu \mathrm{M}$, and oil red O staining was performed at day 8. (B-F) After transfection with control or Glut1 siRNA, the cells were incubated in adipogenic medium containing phloretin $0-100 \mu \mathrm{M}$ for 4 days. The mRNA expression of adipogenic differentiation markers (Ppar $\gamma$, C/ebp $\alpha$, Fas, Fabp4, and Apn) was examined by real-time PCR. The results are expressed as mean $\pm \mathrm{SE}(n \geq 4) ;{ }^{*} p<0.05$, ${ }^{* *} p<0.01,{ }^{* * *} p<0.001$. NC: negative control, Phl: phloretin. 


\section{Discussion}

Previous studies have shown that phloretin affects adipocyte differentiation [17,18] and lipid accumulation [19] in preadipocytes. In the present study, for the first time, we showed that phloretin promoted the commitment of MSCs to adipocytes via the suppression of ERK1/2 and JNK signals and the activation of p38 MAPK. Although phloretin enhanced AMPK phosphorylation, AMPK was not found to be involved in phloretin-induced adipogenesis. Phloretin is a known GLUT inhibitor [12]. However, inhibition of glucose uptake induced by Glut1 silencing did not promote but, rather, suppressed adipogenesis. Moreover, phloretin stimulated adipogenesis even in the Glut1 knocked-down cells, indicating that phloretin's adipogenic effect was not mediated by glucose uptake inhibition.

The involvement of MAPKs in adipogenesis has been reported. However, to our knowledge, there are no studies examining the roles of phloretin-MAPKs signalling in adipocytes so far. It has been reported that ERK signals are required in the stage of mitotic clonal expansion $[2,28,32,33]$, whereas ERK signals suppress adipocyte differentiation in the terminal differentiation phase [2,28,34]. Several studies have shown that the activation of ERK signal suppresses adipocyte differentiation by inhibiting PPAR $\gamma$ activity [35-37]. In this study, phloretin suppressed the phosphorylation of ERK, and ERK inhibition increased PPAR $\gamma$ expression and induced adipogenesis. These findings are consistent with those from previous studies. The role of p38 MAPK in adipogenesis is still controversial. While some studies have demonstrated that activation of p38 MAPK promotes adipogenesis [38-40], opposite results have also been reported [41,42]. Studies by Engelman et al. and Aouadi et al. suggested that p38 MAPK activity may be required in the initial stage of adipogenesis, and that suppression of p38 MAPK may be necessary in the later stage of adipogenesis $[43,44]$. Considering these results, the diverse role of p38 MAPK during adipogenesis might be one possible cause of the discrepancy. The present study demonstrated that transient activation of $\mathrm{p} 38$ MAPK signalling by phloretin promoted adipogenesis. In addition, inhibition of p38 MAPK by phloretin might be associated with its adipogenic effect in the later stage. With regard to JNK signalling, our data suggest that phloretin enhanced adipogenesis via JNK suppression. Although several studies have reported inconsistent results about the role of JNK signalling in adipogenesis [45-50], some studies have reported that inactivation of JNK promotes adipogenesis $[49,50]$, which is consistent with our results. Further studies are necessary to elucidate the roles of JNK signalling in adipogenesis.

AMPK is known to be an intracellular energy sensor and is activated when the intracellular AMP / ATP ratio increases during intracellular energy shortage [22,23]. Therefore, the phloretin-induced AMPK phosphorylation observed in this study may indicate glucose uptake inhibition. It is reported that the pharmacological activation of AMPK suppresses adipogenesis in preadipocytes $[25,26]$. By contrast, we showed that the AMPK inhibitor ara-A did not inhibit phloretin-induced increase in adipogenic marker expression, indicating that AMPK activation by phloretin did not affect adipogenesis. Moreover, while phloretin treatment decreased glucose uptake in ST2 cells, the inhibition of glucose uptake by Glut1 silencing did not increase but, rather, suppressed adipogenesis. These findings are consistent with those of Batchvarova et al. and Carlson et al., who showed that glucose deprivation impaired adipogenesis by upregulation of the C/EBP homologous protein, a negative regulator of adipogenesis, in 3T3-L1 preadipocytes [51,52]. Therefore, the adipogenic effect of phloretin on ST2 cells does not seem to be mediated by AMPK activation or glucose uptake inhibition. Further studies are necessary to clarify the roles of phloretin-induced AMPK activation and glucose uptake inhibition.

Adipose tissue regulates whole body energy metabolism by secreting adipokines in addition to storing redundant nutrients [1]. In vitro and in vivo studies by Shu et al. and Shen et al. demonstrated that oral administration of phloretin decreased the plasma glucose levels in diabetic rodent models [18,20]. APN is one of the adipokines that enhance insulin sensitivity [1]. In the present study, phloretin increased Apn expression, consistent with previous studies $[17,53]$. Therefore, phloretin-induced increase of $A p n$ expression may also contribute to the improvement of glucose 
intolerance caused by phloretin. On the other hand, Alsanea et al. reported that phloretin decreased fat mass and improved obesity, insulin resistance, fatty liver, and inflammation in adipose tissues in a high-fat diet-induced obese mouse model [21]. Thus, phloretin may ameliorate metabolic dysregulation via pleiotropic effects, such as an anti-inflammatory effect, other than its effects on adipogenesis.

In conclusion, our study shows that phloretin enhanced adipogenesis and adiponectin expression by inhibition of ERK1/2 and JNK pathways and activation of p38 MAPK in mouse marrow stromal ST2 cells. Neither glucose uptake inhibition nor AMPK activation were associated with phloretin-induced adipogenic effects. These findings indicate that phloretin may influence energy metabolism by affecting adipogenesis and adiponectin expression.

\section{Materials and Methods}

\subsection{Reagents}

Cell culture medium and supplements were purchased from GIBCO-BRL (Rockville, MD, USA). Phloretin, the AMPK inhibitor ara-A, the MEK inhibitor PD98059, the JNK inhibitor SP600125, the p38 inhibitor SB203580, and the anti- $\beta$ actin antibody were purchased from Sigma-Aldrich (St. Louis, MO, USA). Antibodies against phospho-AMPK $\alpha$ (Thr172), total AMPK $\alpha$, phospho-ERK1/2, total-ERK1/2, phospho-SAPK/JNK, total-SAPK/JNK, phospho-p38 $\alpha$ MAPK, and total-p38 $\alpha$ MAPK were purchased from Cell Signaling Technology (Beverly, MA, USA).

\subsection{Cell Culture}

The mouse MSC line ST2 was purchased from the RIKEN Cell Bank (Tsukuba, Japan). The cells were cultured in $\alpha$-minimum essential medium ( $\alpha$-MEM) supplemented with $10 \%$ fetal bovine serum (FBS) and $1 \%$ penicillin-streptomycin in $5 \% \mathrm{CO}_{2}$ at $37{ }^{\circ} \mathrm{C}$. The medium was changed twice a week, and the cells were passaged when they were $80 \%$ confluent. For adipogenic differentiation, the cells were incubated in $\alpha$-MEM supplemented with $10 \mu \mathrm{g} / \mathrm{mL}$ bovine insulin, $0.5 \mathrm{mM}$ 3-isobutyl-1-methylxanthine, and $2.5 \mu \mathrm{M}$ dexamethasone for 2 days (from day 0 to 2 ), and then incubated in $\alpha$-MEM supplemented with $10 \mu \mathrm{g} / \mathrm{mL}$ bovine insulin for 6 days (from day 2 to 8 ). The medium was changed every 2 days.

\subsection{Oil Red O Staining}

The cells were incubated in adipogenic differentiation media. The cells were washed with phosphate-buffered saline (PBS) twice and fixed with 10\% formalin for $10 \mathrm{~min}$. Then, the cells were washed twice with PBS and treated with $60 \%(v / v)$ isopropanol for $1 \mathrm{~min}$. Following this, isopropanol was aspirated, and oil red O staining was carried out with the addition of $0.3 \%(w / v)$ oil red O (Sigma, St. Louis, MO, USA) in isopropanol/water (60:40) for $20 \mathrm{~min}$ at room temperature. The oil red O stain was removed, and the cells were washed with $60 \%(v / v)$ isopropanol and again with PBS twice. Then, the cells were analysed under a microscope. For the quantification of lipid deposition, the cells were treated with $100 \%$ isopropanol, and the absorbance at $490 \mathrm{~nm}$ was measured with a microplate reader. The results are expressed relative to the control.

\subsection{Quantification of Gene Expression Using Real-Time Polymerase Chain Reaction (PCR)}

Total RNA was extracted from the cultured ST2 cells using TRIzol reagent (Invitrogen, San Diego, CA, USA) according to the manufacturer's recommended protocol. We used $2 \mu \mathrm{g}$ total RNA for the synthesis of single-stranded cDNA (cDNA synthesis kit; Invitrogen). Then, we used SYBR green chemistry to examine the mRNA expression of the adipogenic markers Ppary, C/ebpa, Fas, Fabp4, and Apn, as well as that of Glut1. A housekeeping gene, 3664, was used to normalize the differences in the efficiencies of reverse transcription. The primer sequences are listed in Table 1. Real-time PCR was performed with $1 \mu \mathrm{L}$ of cDNA in a $25 \mu \mathrm{L}$ reaction volume using the Thermal Cycler Dice Real Time System II (Takara Bio, Shiga, Japan). The double-stranded DNA-specific dye SYBR Green I was 
incorporated into the PCR buffer provided in the SYBR Green Real-time PCR Master Mix (Toyobo Co. Ltd., Tokyo, Japan) to enable the quantitative detection of the PCR product. The PCR conditions were: $95{ }^{\circ} \mathrm{C}$ for $15 \mathrm{~min}$, followed by 40 cycles of denaturation at $94{ }^{\circ} \mathrm{C}$ for $15 \mathrm{~s}$, and annealing and extension at $60{ }^{\circ} \mathrm{C}$ for $1 \mathrm{~min}$.

Table 1. Primer sequences used for various genes.

\begin{tabular}{|c|c|c|}
\hline Gene Name & Primers $\left(5^{\prime}-3^{\prime}\right)$ & Accession No. \\
\hline $36 b 4$ & $\begin{array}{l}\text { AAGCGCGTCCTGGCATTGTCT } \\
\text { CCGCAGGGGCAGCAGTGGT }\end{array}$ & NM_007475 \\
\hline Ppary & $\begin{array}{l}\text { GTCTGTGGGGATAAAGCATC } \\
\text { CTGATGGCATTGTGAGACAT }\end{array}$ & NM_001127330.2 \\
\hline Clebp $\alpha$ & $\begin{array}{l}\text { TGAAGGAACTTGAAGCACA } \\
\text { TCAGAGCAAAACCAAAACAA }\end{array}$ & NM_001287521.1 \\
\hline Fas & $\begin{array}{l}\text { CCCTTGATGAAGAGGGATCA } \\
\text { ACTCCACAGGTGGGAACAAG }\end{array}$ & NM_007988.3 \\
\hline Fabp4 & $\begin{array}{l}\text { TGGAAAGTCGACCACCATAAA } \\
\text { GTCACGCCTTTCATGACACA }\end{array}$ & NM_024406.2 \\
\hline Apn & $\begin{array}{l}\text { TGTTGGAATGACAGGAGCTG } \\
\text { TCCTTTTCACAAAGCCACACTAT }\end{array}$ & NM_009605.5 \\
\hline Glut1 & $\begin{array}{c}\text { CGTCGTTGGCATCCTTAT } \\
\text { TTCTTCAGCACACTCTTGG }\end{array}$ & NM_011400.3 \\
\hline
\end{tabular}

\subsection{Western Blot Analysis}

For western blot analysis, the cells were plated in six-well plates and cultured as described above. After reaching confluency, the cells were treated with each agent. The cells were rinsed with ice-cold PBS and scraped on ice into lysis buffer (Bio-Rad, Hercules, CA, USA) containing $65.8 \mathrm{mM}$ Tris-HCl (pH 6.8), 26.3\% (w/v) glycerol, 2.1\% sodium dodecyl sulphate (SDS), and $0.01 \%$ bromophenol blue, to which 2-mercaptoethanol was added to achieve a final concentration of $5 \%$. The cell lysates were sonicated for $20 \mathrm{~s}$. The cell lysates were electrophoresed on 10\% SDS-polyacrylamide gels and transferred onto a nitrocellulose membrane (Bio-Rad). The blots were blocked with Tris-buffered saline (TBS) containing 1\% Tween 20 (Bio-Rad) and 3\% bovine serum albumin (BSA) for $1 \mathrm{~h}$ at $4{ }^{\circ} \mathrm{C}$. Then, the blots were incubated overnight at $4{ }^{\circ} \mathrm{C}$ with gentle shaking with a primary antibody against phosphorylated ERK1/2 (1:2000 dilution) and other primary antibodies (1:1000 dilution). These blots were extensively washed with TBS containing $1 \%$ Tween 20 and were further incubated with a 1:5000 dilution of horseradish peroxidase-coupled IgG of specified animal species (rabbit or mouse) matched to the primary antibodies in TBS for $30 \mathrm{~min}$ at $4{ }^{\circ} \mathrm{C}$. The blots were then washed, and the signal was visualised using an enhanced chemiluminescence technique.

\subsection{RNA Interference for GLUT1}

RNA interference was used to knock down the expression of GLUT1 in ST2 cells. SMARTpool reagents for GLUT1 and non-specific control siRNA duplexes were designed and synthesised by Dharmacon (Lafayette, CO, USA). For gene knockdown experiments, ST2 cells were seeded in six-well plates and cultured at $37{ }^{\circ} \mathrm{C}$ for $48 \mathrm{~h}$ in $\alpha$-MEM containing $10 \%$ FBS and antibiotics, followed by $24 \mathrm{~h}$ of incubation in medium without antibiotics. The cells were transfected with siRNAs (50 nM) using DharmaFECT 1 transfection reagent (Dharmacon, Lafayette, CO, USA) for $24 \mathrm{~h}$ according to the manufacturer's instructions. Then, the cells were incubated in $\alpha$-MEM supplemented with $10 \%$ FBS and antibiotics for additional $24 \mathrm{~h}$ to reach confluency. 


\subsection{Reverse Transcription PCR (RT-PCR) Analysis to Determine the Expression of GLUT1}

To confirm the silencing efficiency of Glut1 mRNA by siRNA, we performed RT-PCR. After siRNA transfection, total RNA was extracted using TRIzol reagent (Invitrogen, San Diego, CA) according to the manufacturer's recommended protocol. We used $2 \mu \mathrm{g}$ total RNA for the synthesis of single-stranded cDNA (cDNA synthesis kit; Invitrogen). The PCR conditions were as follows: denaturation at $94.0^{\circ} \mathrm{C}$ for $45 \mathrm{~s}$, annealing at $60.0^{\circ} \mathrm{C}$ for $30 \mathrm{~s}$, and elongation at $72{ }^{\circ} \mathrm{C}$ for $45 \mathrm{~s}$ for 30 cycles. The PCR products were separated by electrophoresis on a $1.8 \%$ agarose gel and were visualised using ethidium bromide staining with ultraviolet (UV) light, using the Electronic UV transilluminator (Toyobo Co. Ltd.).

\subsection{2-DG Uptake Colorimetric Assay}

To examine the effects of phloretin and Glut1 silencing on glucose uptake, glucose uptake was examined using a Glucose Uptake Assay Kit (BioVision, Hannover, Germany). The cells were incubated in 96-well plates until they reached confluency. The cells were starved for glucose by incubating in KRPH buffer (20 mM HEPES, $5 \mathrm{mM} \mathrm{KH}_{2} \mathrm{PO}_{4}, 1 \mathrm{mM} \mathrm{MgSO} 4,1 \mathrm{mM} \mathrm{CaCl}_{2}, 136 \mathrm{mM} \mathrm{NaCl}$, and $4.7 \mathrm{mM}$ $\mathrm{KCl}, \mathrm{pH} 7.4)$ containing $2 \% \mathrm{BSA}$ with phloretin $(0$ to $100 \mu \mathrm{M})$ for $20 \mathrm{~min}$. After the buffer was removed, the cells were further incubated with $10 \mu \mathrm{L}$ of $10 \mathrm{mM}$ 2-DG and phloretin $(0$ to $100 \mu \mathrm{M})$ for $20 \mathrm{~min}$. The Reaction Mix A (total $10 \mu \mathrm{L}$ : assay buffer $8 \mu \mathrm{L}$ and enzyme mix $2 \mu \mathrm{L}$ ) was added and the cells were incubated for $60 \mathrm{~min}$. The extraction buffer $(90 \mu \mathrm{L})$ was added and the cells were incubated at $85.0^{\circ} \mathrm{C}$ for $40 \mathrm{~min}$. The plate was cooled on ice for $5 \mathrm{~min}$, and $12 \mu \mathrm{L}$ neutralization buffer was added. Thereafter, the Reaction Mix B (total $38 \mu \mathrm{L}$ : glutathione reductase $20 \mu \mathrm{L}$, substrate DTNB $16 \mu \mathrm{L}$, and recycling mix $2 \mu \mathrm{L}$ ) was added, and the absorbance at $405 \mathrm{~nm}$ was measured with a microplate reader. The amount of 2-DG uptake is proportional to the absorbance. The results are expressed relative to the control.

\subsection{Statistics}

The results are expressed as means \pm standard error of mean (SEM). Statistical evaluations for differences between groups were performed using one-way analysis of variance (ANOVA) followed by Fisher's protected least significant difference test. For all statistical tests, a value of $p<0.05$ was considered statistically significant.

Author Contributions: A.T. and I.K. designed the study. A.T. performed the experiments. A.T., I.K., M.N., K.T., and T.S. analyzed and discussed the data. A.T. and I.K. wrote the paper. All authors read and approved the final manuscript.

Acknowledgments: The authors thank Keiko Nagira for technical assistance.

Conflicts of Interest: The authors declare no conflict of interest.

\section{Abbreviations}

$\begin{array}{ll}\text { APN } & \text { adiponectin } \\ \text { C/EBP } & \text { CCAAT/enhancer-binding protein } \\ \text { PPAR } \gamma & \text { peroxisome proliferator-activated receptor } \gamma \\ \text { GLUT } & \text { glucose transporter } \\ \text { MSC } & \text { marrow stromal cell } \\ \text { AMPK } & \text { adenosine monophosphate-activated protein kinase } \\ \text { MAPK } & \text { mitogen-activated protein kinase } \\ \text { ERK } & \text { extracellular signal-regulated kinase } \\ \text { JNK } & \text { c-Jun N-terminal kinase } \\ \text { MEK } & \text { MAPK/ERK kinase } \\ \alpha \text {-MEM } & \alpha \text {-minimum essential medium } \\ \text { FBS } & \text { fetal bovine serum } \\ \text { PBS } & \text { phosphate-buffered saline } \\ \text { PCR } & \text { polymerase chain reaction }\end{array}$




$\begin{array}{ll}\text { FAS } & \text { fatty acid synthase } \\ \text { FABP4 } & \text { fatty acid-binding protein } 4 \\ \text { SDS } & \text { sodium dodecyl sulphate } \\ \text { TBS } & \text { Tris-buffered saline } \\ \text { BSA } & \text { bovine serum albumin } \\ \text { siRNA } & \text { small interfering RNA } \\ \text { UV } & \text { ultraviolet } \\ \text { 2-DG } & \text { 2-deoxyglucose } \\ \text { KRPH buffer } & \text { Krebs-Ringer Phosphate-Hepes buffer } \\ \text { SEM } & \text { standard error of mean } \\ \text { ANOVA } & \text { analysis of variance }\end{array}$

\section{References}

1. Galic, S.; Oakhill, J.S.; Steinberg, G.R. Adipose tissue as an endocrine organ. Mol. Cell. Endocrinol. 2010, 316, 129-139. [CrossRef] [PubMed]

2. Rosen, E.D.; MacDougald, O.A. Adipocyte differentiation from the inside out. Nat. Rev. Mol. Cell Biol. 2006, 7, 885-896. [CrossRef] [PubMed]

3. Cristancho, A.G.; Lazar, M.A. Forming functional fat: A growing understanding of adipocyte differentiation. Nat. Rev. Mol. Cell Biol. 2011, 12, 722-734. [CrossRef] [PubMed]

4. Chamberlain, G.; Fox, J.; Ashton, B.; Middleton, J. Concise review: Mesenchymal stem cells: Their phenotype, differentiation capacity, immunological features, and potential for homing. Stem Cells 2007, 25, 2739-2749. [CrossRef] [PubMed]

5. Lee, K.W.; Kim, Y.J.; Kim, D.O.; Lee, H.J.; Lee, C.Y. Major phenolics in apple and their contribution to the total antioxidant capacity. J. Agric. Food Chem. 2003, 51, 6516-6520. [CrossRef] [PubMed]

6. Hilt, P.; Schieber, A.; Yildirim, C.; Arnold, G.; Klaiber, I.; Conrad, J.; Beifuss, U.; Carle, R. Detection of phloridzin in strawberries (Fragaria $\times$ ananassa Duch.) by HPLC-PDA-MS/MS and NMR spectroscopy. J. Agric. Food Chem. 2003, 51, 2896-2899. [CrossRef] [PubMed]

7. Rezk, B.M.; Haenen, G.R.; van der Vijgh, W.J.; Bast, A. The antioxidant activity of phloretin: The disclosure of a new antioxidant pharmacophore in flavonoids. Biochem. Biophys. Res. Commun. 2002, 295, 9-13. [CrossRef]

8. Yang, Y.C.; Lii, C.K.; Lin, A.H.; Yeh, Y.W.; Yao, H.T.; Li, C.C.; Liu, K.L.; Chen, H.W. Induction of glutathione synthesis and heme oxygenase 1 by the flavonoids butein and phloretin is mediated through the ERK/Nrf2 pathway and protects against oxidative stress. Free Radic. Biol. Med. 2011, 51, 2073-2081. [CrossRef] [PubMed]

9. Liu, Y.; Zhang, L.; Liang, J. Activation of the Nrf2 defense pathway contributes to neuroprotective effects of phloretin on oxidative stress injury after cerebral ischemia/reperfusion in rats. J. Neurol. Sci. 2015, 351, 88-92. [CrossRef] [PubMed]

10. Wang, S.P.; Lin, S.C.; Li, S.; Chao, Y.H.; Hwang, G.Y.; Lin, C.C. Potent antiarthritic properties of phloretin in murine collagen-induced arthritis. Evid. Based Complement. Altern. Med. 2016, 2016, 9831263. [CrossRef] [PubMed]

11. Huang, W.C.; Wu, S.J.; Tu, R.S.; Lai, Y.R.; Liou, C.J. Phloretin inhibits interleukin-1ß-induced COX-2 and ICAM-1 expression through inhibition of MAPK, Akt, and NF- $\mathrm{kB}$ signaling in human lung epithelial cells. Food Funct. 2015, 6, 1960-1967. [CrossRef] [PubMed]

12. Ehrenkranz, J.R.; Lewis, N.G.; Kahn, C.R.; Roth, J. Phlorizin: A review. Diabetes Metab. Res. Rev. 2005, 21, 31-38. [CrossRef] [PubMed]

13. Tu, S.H.; Chen, L.C.; Ho, Y.S. An apple a day to prevent cancer formation: Reducing cancer risk with flavonoids. J. Food Drug Anal. 2017, 25, 119-124. [CrossRef] [PubMed]

14. Wu, C.H.; Ho, Y.S.; Tsai, C.Y.; Wang, Y.J.; Tseng, H.; Wei, P.L.; Lee, C.H.; Liu, R.S.; Lin, S.Y. In vitro and in vivo study of phloretin-induced apoptosis in human liver cancer cells involving inhibition of type II glucose transporter. Int. J. Cancer 2009, 124, 2210-2219. [CrossRef] [PubMed]

15. Hsieh, I.S.; Yang, R.S.; Fu, W.M. Osteopontin upregulates the expression of glucose transporters in osteosarcoma cells. PLoS ONE 2014, 9, e109550. [CrossRef] [PubMed] 
16. Lin, S.T.; Tu, S.H.; Yang, P.S.; Hsu, S.P.; Lee, W.H.; Ho, C.T.; Wu, C.H.; Lai, Y.H.; Chen, M.Y.; Chen, L.C. Apple polyphenol phloretin inhibits colorectal cancer cell growth via inhibition of the type 2 glucose transporter and activation of p53-mediated signaling. J. Agric. Food Chem. 2016, 64, 6826-6837. [CrossRef] [PubMed]

17. Hassan, M.; El Yazidi, C.; Landrier, J.F.; Lairon, D.; Margotat, A.; Amiot, M.J. Phloretin enhances adipocyte differentiation and adiponectin expression in 3T3-L1 cells. Biochem. Biophys. Res. Commun. 2007, 361, $208-213$. [CrossRef] [PubMed]

18. Shu, G.; Lu, N.S.; Zhu, X.T.; Xu, Y.; Du, M.Q.; Xie, Q.P.; Zhu, C.J.; Xu, Q.; Wang, S.B.; Wang, L.N.; et al. Phloretin promotes adipocyte differentiation in vitro and improves glucose homeostasis in vivo. J. Nutr. Biochem. 2014, 25, 1296-1308. [CrossRef] [PubMed]

19. Huang, W.C.; Chang, W.T.; Wu, S.J.; Xu, P.Y.; Ting, N.C.; Liou, C.J. Phloretin and phlorizin promote lipolysis and inhibit inflammation in mouse 3T3-L1 cells and in macrophage-adipocyte co-cultures. Mol. Nutr. Food Res. 2013, 57, 1803-1813. [CrossRef] [PubMed]

20. Shen, X.; Zhou, N.; Mi, L.; Hu, Z.; Wang, L.; Liu, X.; Zhang, S. Phloretin exerts hypoglycemic effect in streptozotocin-induced diabetic rats and improves insulin resistance in vitro. Drug Des. Dev. Ther. 2017, 11, 313-324. [CrossRef] [PubMed]

21. Alsanea, S.; Gao, M.; Liu, D. phloretin prevents high-fat diet-induced obesity and improves metabolic homeostasis. AAPS J. 2017, 19, 797-805. [CrossRef] [PubMed]

22. Kahn, B.B.; Alquier, T.; Carling, D.; Hardie, D.G. AMP-activated protein kinase: Ancient energy gauge provides clues to modern understanding of metabolism. Cell Metab. 2005, 1, 15-25. [CrossRef] [PubMed]

23. Kola, B.; Boscaro, M.; Rutter, G.A.; Grossman, A.B.; Korbonits, M. Expanding role of AMPK in endocrinology. Trends Endocrinol. Metab. 2006, 17, 205-215. [CrossRef] [PubMed]

24. Kim, E.K.; Lim, S.; Park, J.M.; Seo, J.K.; Kim, J.H.; Kim, K.T.; Ryu, S.H.; Suh, P.G. Human mesenchymal stem cell differentiation to the osteogenic or adipogenic lineage is regulated by AMP-activated protein kinase. J. Cell Physiol. 2012, 227, 1680-1687. [CrossRef] [PubMed]

25. Habinowski, S.A.; Witters, L.A. The effects of AICAR on adipocyte differentiation of 3T3-L1 cells. Biochem. Biophys. Res. Commun. 2001, 286, 852-856. [CrossRef] [PubMed]

26. Lee, H.; Kang, R.; Bae, S.; Yoon, Y. AICAR, an activator of AMPK, inhibits adipogenesis via the WNT/ $\beta$-catenin pathway in 3T3-L1 adipocytes. Int. J. Mol. Med. 2011, 28, 65-71. [PubMed]

27. Wang, Y.G.; Han, X.G.; Yang, Y.; Qiao, H.; Dai, K.R.; Fan, Q.M.; Tang, T.T. Functional differences between AMPK $\alpha 1$ and $\alpha 2$ subunits in osteogenesis, osteoblast-associated induction of osteoclastogenesis, and adipogenesis. Sci. Rep. 2016, 6, 32771. [CrossRef] [PubMed]

28. Bost, F.; Aouadi, M.; Caron, L.; Binetruy, B. The role of MAPKs in adipocyte differentiation and obesity. Biochimie 2005, 87, 51-56. [CrossRef] [PubMed]

29. Takeno, A.; Kanazawa, I.; Notsu, M.; Tanaka, K.I.; Sugimoto, T. Glucose uptake inhibition decreases expressions of receptor activator of nuclear factor- $\mathrm{K} B$ ligand (RANKL) and osteocalcin in osteocytic MLO-Y4-A2 cells. Am. J. Physiol. Endocrinol. Metab. 2018, 314, E115-E123. [CrossRef] [PubMed]

30. Choi, B.M.; Chen, X.Y.; Gao, S.S.; Zhu, R.; Kim, B.R. Anti-apoptotic effect of phloretin on cisplatin-induced apoptosis in HEI-OC1 auditory cells. Pharmacol. Rep. 2011, 63, 708-716. [CrossRef]

31. Min, J.; Huang, K.; Tang, H.; Ding, X.; Qi, C.; Qin, X.; Xu, Z. Phloretin induces apoptosis of non-small cell lung carcinoma A549 cells via JNK1/2 and p38 MAPK pathways. Oncol. Rep. 2015, 34, 2871-2879. [CrossRef] [PubMed]

32. Prusty, D.; Park, B.H.; Davis, K.E.; Farmer, S.R. Activation of MEK/ERK signaling promotes adipogenesis by enhancing peroxisome proliferator-activated receptor $\lambda(\operatorname{PPAR} \lambda)$ and $\mathrm{C} / \mathrm{EBP} \alpha$ gene expression during the differentiation of 3T3-L1 preadipocytes. J. Biol. Chem. 2002, 277, 46226-46232. [CrossRef] [PubMed]

33. Bost, F.; Caron, L.; Marchetti, I.; Dani, C.; Le Marchand-Brustel, Y.; Binetruy, B. Retinoic acid activation of the ERK pathway is required for embryonic stem cell commitment into the adipocyte lineage. Biochem. J. 2002, 361, 621-627. [CrossRef] [PubMed]

34. Jaiswal, R.K.; Jaiswal, N.; Bruder, S.P.; Mbalaviele, G.; Marshak, D.R.; Pittenger, M.F. Adult human mesenchymal stem cell differentiation to the osteogenic or adipogenic lineage is regulated by mitogen-activated protein kinase. J. Biol. Chem. 2000, 275, 9645-9652. [CrossRef] [PubMed]

35. Ge, C.; Cawthorn, W.P.; Li, Y.; Zhao, G.; Macdougald, O.A.; Franceschi, R.T. Reciprocal Control of Osteogenic and Adipogenic Differentiation by ERK/MAP Kinase Phosphorylation of Runx2 and PPAR $\lambda$ Transcription Factors. J. Cell Physiol. 2016, 231, 587-596. [CrossRef] [PubMed] 
36. Hu, E.; Kim, J.B.; Sarraf, P.; Spiegelman, B.M. Inhibition of adipogenesis through MAP kinase-mediated phosphorylation of PPAR $\lambda$. Science 1996, 274, 2100-2103. [CrossRef] [PubMed]

37. Adams, M.; Reginato, M.J.; Shao, D.; Lazar, M.A.; Chatterjee, V.K. Transcriptional activation by peroxisome proliferator-activated receptor $\lambda$ is inhibited by phosphorylation at a consensus mitogen-activated protein kinase site. J. Biol. Chem. 1997, 272, 5128-5132. [CrossRef] [PubMed]

38. Engelman, J.A.; Lisanti, M.P.; Scherer, P.E. Specific inhibitors of p38 mitogen-activated protein kinase block 3T3-L1 adipogenesis. J. Biol. Chem. 1998, 273, 32111-32120. [CrossRef] [PubMed]

39. Ji, J.; Zhu, J.; Hu, X.; Wang, T.; Zhang, X.; Hou, A.J.; Wang, H. (2S)-7,4'-dihydroxy-8-prenylflavan stimulates adipogenesis and glucose uptake through p38MAPK pathway in 3T3-L1 cells. Biochem. Biophys. Res. Commun. 2015, 460, 578-582. [CrossRef] [PubMed]

40. Aouadi, M.; Jager, J.; Laurent, K.; Gonzalez, T.; Cormont, M.; Binetruy, B.; Le Marchand-Brustel, Y.; Tanti, J.F.; Bost, F. p38MAP Kinase activity is required for human primary adipocyte differentiation. FEBS Lett. 2007, 581, 5591-5596. [CrossRef] [PubMed]

41. Cong, Q.; Jia, H.; Biswas, S.; Li, P.; Qiu, S.; Deng, Q.; Guo, X.; Ma, G.; Chau, J.F.L.; Wang, Y.; et al. p38 $\alpha$ MAPK regulates lineage commitment and OPG synthesis of bone marrow stromal cells to prevent bone loss under physiological and pathological conditions. Stem Cell Rep. 2016, 6, 566-578. [CrossRef] [PubMed]

42. Liu, G.X.; Zhu, J.C.; Chen, X.Y.; Zhu, A.Z.; Liu, C.C.; Lai, Q.; Chen, S.T. Inhibition of adipogenic differentiation of bone marrow mesenchymal stem cells by erythropoietin via activating ERK and P38 MAPK. Genet. Mol. Res. 2015, 14, 6968-6977. [CrossRef] [PubMed]

43. Engelman, J.A.; Berg, A.H.; Lewis, R.Y.; Lin, A.; Lisanti, M.P.; Scherer, P.E. Constitutively active mitogen-activated protein kinase kinase 6 (MKK6) or salicylate induces spontaneous 3T3-L1 adipogenesis. J. Biol. Chem. 1999, 274, 35630-35638. [CrossRef] [PubMed]

44. Aouadi, M.; Laurent, K.; Prot, M.; Le Marchand-Brustel, Y.; Binetruy, B.; Bost, F. Inhibition of p38MAPK increases adipogenesis from embryonic to adult stages. Diabetes 2006, 55, 281-289. [CrossRef] [PubMed]

45. Zhang, T.; Sawada, K.; Yamamoto, N.; Ashida, H. 4-Hydroxyderricin and xanthoangelol from Ashitaba (Angelica keiskei) suppress differentiation of preadiopocytes to adipocytes via AMPK and MAPK pathways. Mol. Nutr. Food Res. 2013, 57, 1729-1740. [CrossRef] [PubMed]

46. Li, D.; Zhang, R.; Zhu, W.; Xue, Y.; Zhang, Y.; Huang, Q.; Liu, M.; Liu, Y. S100A16 inhibits osteogenesis but stimulates adipogenesis. Mol. Biol. Rep. 2013, 40, 3465-3473. [CrossRef] [PubMed]

47. Shen, Y.; Zhao, Y.; Zheng, D.; Chang, X.; Ju, S.; Guo, L. Effects of orexin A on GLUT4 expression and lipid content via MAPK signaling in 3T3-L1 adipocytes. J. Steroid Biochem. Mol. Biol. 2013, 138, 376-383. [CrossRef] [PubMed]

48. Du, L.; Fan, H.; Miao, H.; Zhao, G.; Hou, Y. Extremely low frequency magnetic fields inhibit adipogenesis of human mesenchymal stem cells. Bioelectromagnetics 2014, 35, 519-530. [CrossRef] [PubMed]

49. Liu, S.; Xu, R.; Gerin, I.; Cawthorn, W.P.; Macdougald, O.A.; Chen, X.W.; Saltiel, A.R.; Koenig, R.J.; Xu, B. SRA regulates adipogenesis by modulating $\mathrm{p} 38 / \mathrm{JNK}$ phosphorylation and stimulating insulin receptor gene expression and downstream signaling. PLoS ONE 2014, 9, e95416. [CrossRef] [PubMed]

50. Gu, H.; Huang, Z.; Yin, X.; Zhang, J.; Gong, L.; Chen, J.; Rong, K.; Xu, J.; Lu, L.; Cui, L. Role of c-Jun $\mathrm{N}$-terminal kinase in the osteogenic and adipogenic differentiation of human adipose-derived mesenchymal stem cells. Exp. Cell Res. 2015, 339, 112-121. [CrossRef] [PubMed]

51. Batchvarova, N.; Wang, X.Z.; Ron, D. Inhibition of adipogenesis by the stress-induced protein CHOP (Gadd153). EMBO J. 1995, 14, 4654-4661. [PubMed]

52. Carlson, S.G.; Fawcett, T.W.; Bartlett, J.D.; Bernier, M.; Holbrook, N.J. Regulation of the C/EBP-related gene gadd153 by glucose deprivation. Mol. Cell. Biol. 1993, 13, 4736-4744. [CrossRef] [PubMed]

53. Hassan, M.; El Yazidi, C.; Malezet-Desmoulins, C.; Amiot, M.J.; Margotat, A. Gene expression profiling of 3T3-L1 adipocytes exposed to phloretin. J. Nutr. Biochem. 2010, 21, 645-652. [CrossRef] [PubMed]

(C) 2018 by the authors. Licensee MDPI, Basel, Switzerland. This article is an open access article distributed under the terms and conditions of the Creative Commons Attribution (CC BY) license (http://creativecommons.org/licenses/by/4.0/). 